\title{
The Eastman Jubilee 1948 - 1998*
}

\author{
Malcolm Harris 1
}

The postgraduate Eastman Dental Clinic and Institute of Dental Surgery were established in 1947. However their roots go back to Rochester in New York State where George Eastman was born in 1854. George Eastman literally changed the image of the world by creating popular photography. In 1914 he was driven by his painful neglected dentition to seek the help of Harvey Jacob Burkhart (pictured, right) who was considered to be the best dentist in the state. ${ }^{1}$ Burkhart provided him, for the first time in his adult life, with comfortable dentures, which not only restored function but also his appearance. George Eastman was overwhelmed with his new found comfort and social confidence.

Burkhart had no difficulty in persuading Bhis patient that the lack of dental care in childhood had far reaching disastrous effects in adult life and so in 1915 Eastman agreed to augment the funding of the Rochester Dental Dispensary. However, impressed by the new Forsyth Dental Clinic in Boston, he decided to build a new Rochester Dental Dispensary dedicated to the eradication of diseases of the mouth, nose and throat in children that was opened in 1917 at a cost of $\$ 403,000$.

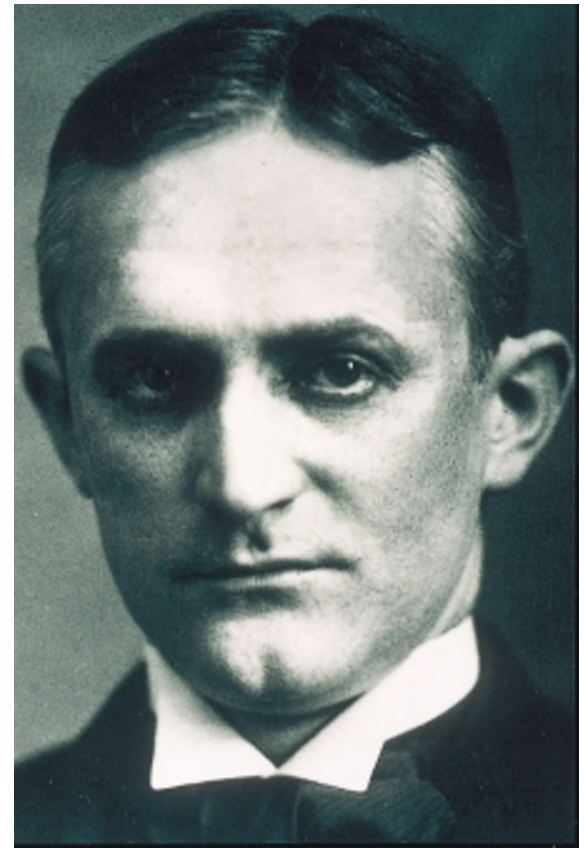

George Eastman, 1900
Burkhart was made director and displayed his genius as one of the founding fathers of dental public health by insisting that preventive dentistry would not be possible without a new profession of dental hygienists who would examine mouths from the emergence of the first tooth, advise mothers on oral hygiene and dietary care and take their instruments, a special chair and a steriliser, to carry out inspections in schools and refer the young patients back to the dispensary.

Burkhart's view of dental education and training was influenced by Abraham Flexner the author of the seminal 1910 Carnegie report on American Medical Education ${ }^{2}$ and he planned the dispensary to become an undergraduate dental school when Rochester acquired a medical school to provide the educational base for dental training.

Flexner anticipated both Cochrane and Calman when he argued the case for scientifically based medical education at an undergraduate and postgraduate level. $\mathrm{He}$ also insisted that structured postgraduate hospital training programmes should be designed and inspected ${ }^{3,4}$. With this in mind Burkhart's Dental Dispensary provided the first structured training programmes in children's dentistry including orthodontics for new graduates. But he failed to get on with George Hoyt Whipple the Dean of the new Rochester Medical School $^{5}$ and so his Dental Dispensary remained a children's clinic which became the Eastman Dental Centre after Eastman's

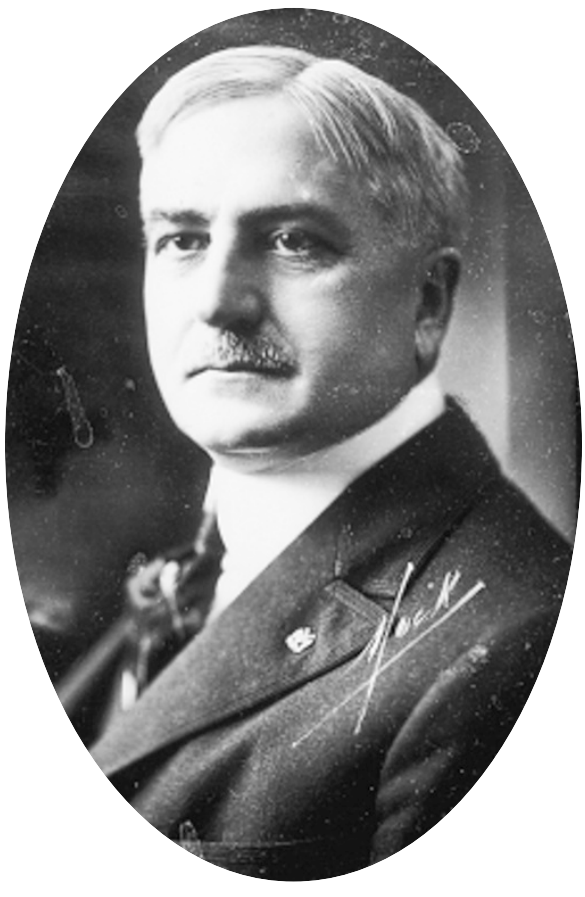

death but only merged with the Rochester Medical Centre in 1998, 46 years after Burkhart's death.

\section{The Eastman Dental Clinic London 1930}

In 1926 George Eastman was approached by Lord Riddell, the Chairman of the Royal Free Hospital, to fund a dental clinic in Lon-

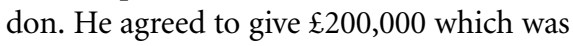

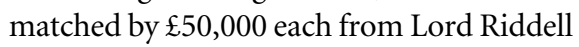
and Sir Albert Levy, the Royal Free honorary treasurer.

The Eastman Dental Clinic was opened in 20 November 1931 by the American Ambassador in the presence of Neville Chamberlain.

The building, which resembled the Rochester Dispensary, was totally integrated into the Royal Free Hospital and included three wards for oral, ear nose and throat and cleft lip and palate surgery and was dedicated to providing dental care for children from the poor districts of central London.

${ }^{*}$ Text of a lecture given by Malcolm Harris on December 17, 1998, on the occasion of the Eastman Jubilee 1948 -1998.

${ }^{1}$ Malcolm Harris, Department of Oral and Maxillofacial Surgery Eastman Dental Institute, University College, London WC1X 8LD (C) British Dental Journal 2000; 188: 647-652 


\section{OPINION personal view}

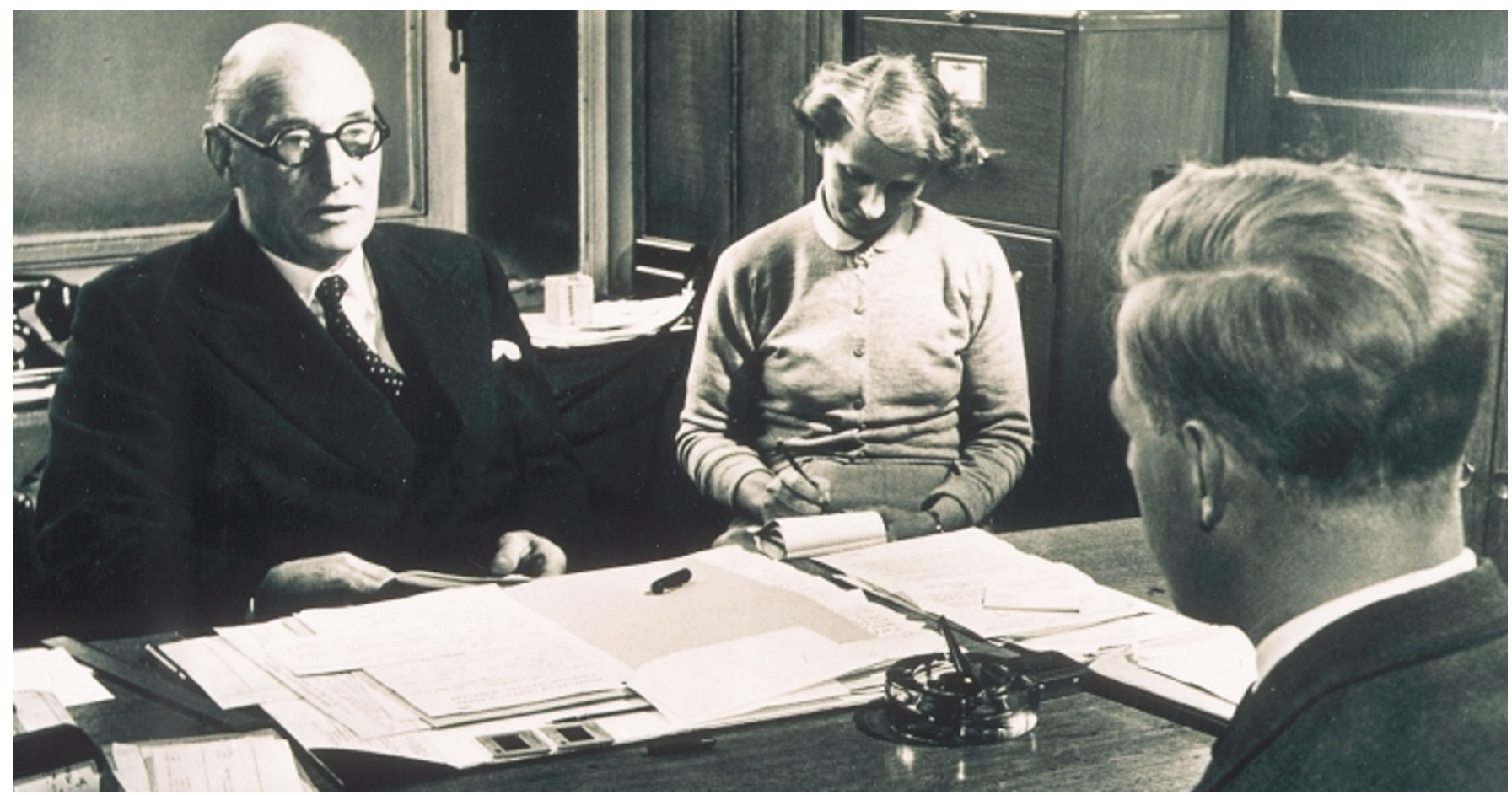

Professor Frank Wilkinson interviewing a potential trainee

By the time the Royal Free Clinic was opened, Eastman was ill, in constant pain and had great difficulty in moving. The Mayo Clinic gave a corporate diagnosis of atherosclerosis of the spinal cord, which today with modern imaging would probably have been spinal stenosis. After many weeks of careful reworking of his will, he placed a towel over his chest and shot himself with a Luger pistol on Monday 14 March 1932.

He left a message: 'To my friends, my work is done. Why wait?' He had donated $\mathfrak{E} 18$ million to education, the arts and charitable causes

\section{The Institute of Dental Surgery and Eastman Dental Hospital.}

Although Endicott ${ }^{6}$ the first director of the Eastman and Ballard ${ }^{7}$ had both argued for a multidisciplinary teaching clinic it was not achieved until 1947 and 1948 when the Eastman became independent of the Royal Free and was established as the postgraduate dental institute of the Postgraduate Medical Federation.

The Objects of the Institute were stated as follows ;

The training of consultants, specialists and teachers, in various branches of dentistry. To provide facilities for and encourage research by members of staff and students. To provide clinical and laboratory facilities and instruction for candidates working for higher degrees or diplomas. To provide short courses for general practitioners, in so far as it is possible to do so without

\section{He placed a towel over} his chest and shot himself on Monday 14 March 1932. He left a message: 'To my friends, my work is done. Why wait?' He had donated $\mathfrak{1} 18$ million to education, the arts and charitable

\section{causes}

interfering with the main objects as set out above.

The parallel establishment of the Faculty of Dental Surgery in 1948 at the Royal College of Surgeons by Professor Robert Bradlaw, together with the creation of the Dental Fellowship examination were crucial to the future role of the Institute and Hospital in postgraduate dental education and training throughout the country and world-wide.

The director of the new Eastman Clinic, Alan Deverell became the first Dean of the Institute in 1948 until $1950^{8}$. In 1948 there were only four heads of department: George Cross - Periodontology, Gilbert
Parfitt - Preventive Dentistry, Guy Morrant - Conservation and Clifford Ballard Orthodontics. The Institute also inherited Victor Goldman as a consultant anaesthetist from the Royal Free. A key appointment was the chief technician A E Denison, who established technicians courses, materials science development and taught clinicians up until 1970. In 1949 a department of pathology and microbiology was created by Ivor Kramer and the first civilian oral hygienist school in the UK was opened by Guy Poyton and Vera Creaton.

In 1950, as free primary dental care was available throughout the country, the Eastman Clinic ceased to provide routine treatment apart from retaining a casualty service and its name was changed to the Eastman Dental Hospital.

Deverell was a charming man and a highly competent consultant but could not cope with the rapidly expanding educational structure of the Institute and so in 1950 Professor Frank Wilkinson was appointed Dean.

\section{Professor Frank Wilkinson (1950 -1959)}

Professor Frank Wilkinson was academically experienced and had been the Dean at Melbourne and Manchester. $\mathrm{He}$ was dynamic, did not suffer fools gladly but was intensely loyal to his staff and trainees. ${ }^{9} \mathrm{He}$ established a full range of departments including 'Children's' run by RR (Dick) Stephens, his own department of Oral Surgery, Prosthetics under John H Lee and 


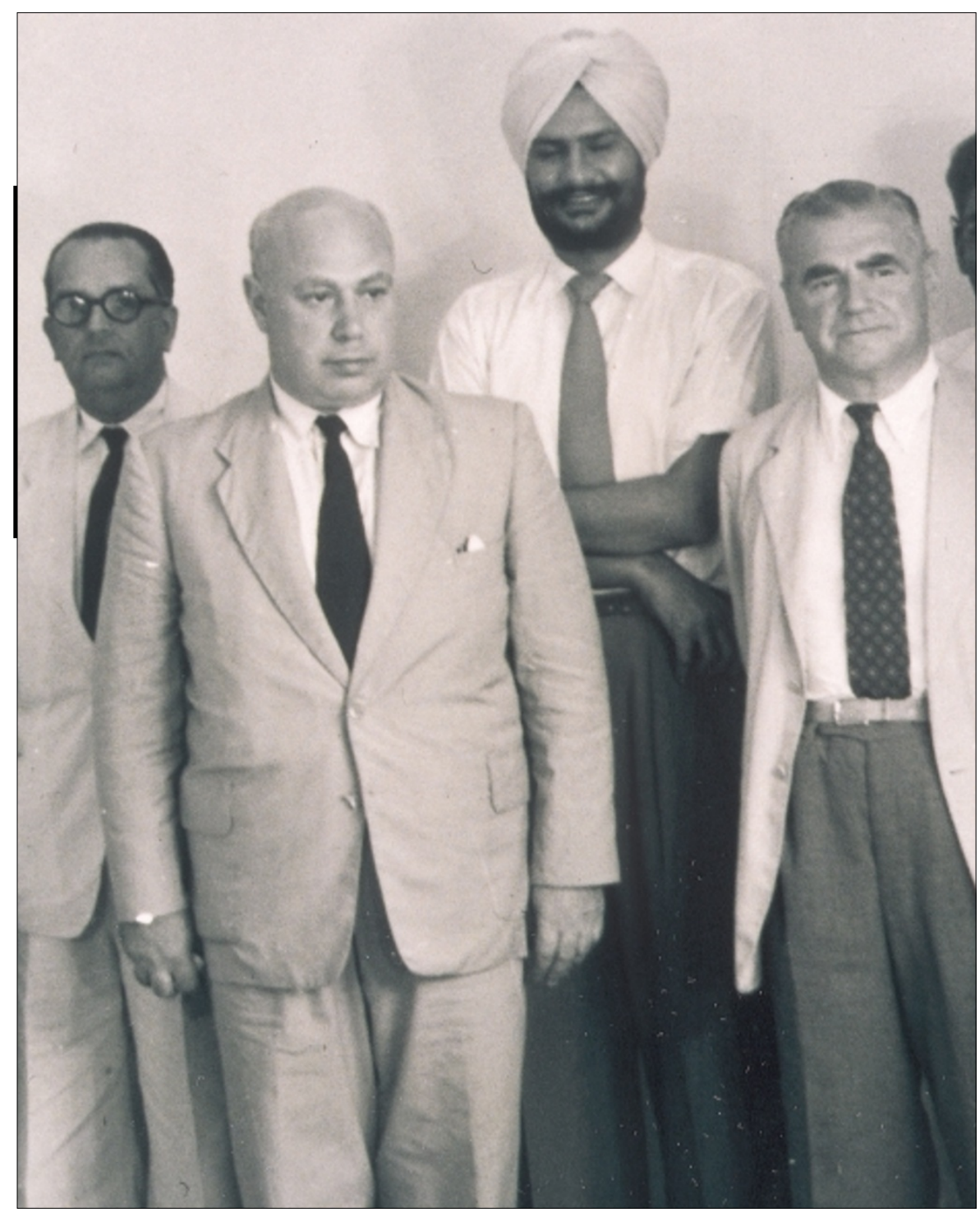

Professor Sir Robert Bradlaw as chairman of the first overseas primary fellowship examination held in Colombo in 1958. To his left is one of the successful candidates, Hardev Coonar who had come down from Amritsar to take the examination.

Radiography under Frank Ingram.

In 1950 there were 28 whole time students and trainees for Fellowship and specialist courses varying from six months to a year. Short courses were attended by $124 \mathrm{stu}-$ dents and the fees were collected in guineas.

None sat a university exam and only one $\mathrm{PhD}$ was registered. However 18 Eastman trainees presented for the FDSRCS and 13 were successful.

With Frank Wilkinson's international connections, the Eastman ('Eastmans') became an international centre of excellence for higher training. Although 55\% of trainees were from the UK, $30 \%$ came from the Commonwealth and 14\% from elsewhere, making 22 countries in all. A regular feature was training programmes for the armed forces dental officers.

By 1956, a review showed at least 56 of the previous six years students and trainees had achieved significant appointments; five had been appointed to Chairs, one reader, 11 senior lecturers and departmental heads, 17 lecturers, 10 consultants, and 12 orthodontic specialists.

In 1959 Wilkinson reluctantly resigned at the age of 70 having established an internationally recognised multidisciplinary postgraduate dental school. ${ }^{10}$

\section{Sir Robert Bradlaw, Dean 1959 - 1970}

Robert Bradlaw had been Dean at Newcastle and brought a close relationship with the College of Surgeons and the Department of
Health. He consolidated the international role of the Eastman as a postgraduate school and created a department of Oral Medicine. He also brought an avuncular eccentricity to the place.

In 1967, in anticipation of the departure of the Royal Free, plans to rebuild the Eastman on the St. Mary's site started. This was supported by the Flowers report, although at least two years earlier there had been a proposal to build a multidisciplinary Holborn Postgraduate Centre on the Royal Free site but there was not sufficient vision to wait for the area to be vacated. ${ }^{11}$

At the same time in 1968, the whole ethos of Eastman teaching changed with the introduction of MSc courses of the University of London, which were to displace the long general subjects course for FDSRCS. These were degree programmes with a dissertation by research creating a new challenge for students and staff alike.

\section{Professor Ivor Kramer (1970-1983)}

Ivor Kramer had served as deputy Dean since 1950 and was an ideal successor to the deanship.

By 1978/1979, students now attended the Institute from 38 countries to be taught by a staff of 50. The MSc programmes had developed in numbers and length (Table 1).

Although superficially a period of calm educational development exemplified by the immaculate Kramer lectures, there was for the first time a strong undercurrent of change with the anticipated move to the St Mary's site.

Kodak gave $\mathfrak{E} 100,000$ to help establish new research laboratories and the Postgraduate Medical Federation was about to be dismantled with the merger of all the specialist institutes and their hospitals with multidisciplinary undergraduate teaching hospitals.

The Royal Free Hospital moved to Hampstead in 1974, but in 1975, with the collapse of the economy and local planning problems, Dr David Owen - Secretary of State for Health - decreed that the Eastman/St. Mary's build was to halt at the stage when the plans were advanced as far as the choice of light switches and coat hooks. 
This left the Eastman isolated and so began an intense battle for expansion and development essential for survival. A plan to move the Eastman into two floors of the Guy's Tower block came to nought.

By 1979 in order to overcome the shortage of space, an oral surgery research laboratory was set up in the former orthopaedic plaster room in the derelict Levy wing of the Royal Free. This modest group of four squatters created the first of the future Eastman Research Laboratories.

The North East Thames Regional Health Authority were eager to take over the building as its regional headquarters and failed to mention the Eastman's need of the building in their submission to a public enquiry. This was successfully rumbled by the Dean, Ivor Kramer, Nat Puri the Institute architect, Steve Gould Chairman of the Hospital Committee and Ernie Taylor and Caroline Fox, the hospital secretary and assistant secretary who worked through the night to put in the Eastman bid. This was successful, but the Department of Health repeatedly refused to agree to the proposed site changes. Eventually Ivor Kramer uncharacteristically stormed down Whitehall and firmly persuaded the civil servants to fund the expansion without which the Eastman could not have survived. And so the old Royal Free Hospital site was acquired from the North East Thames Regional Health

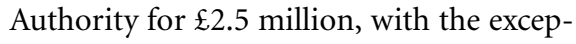
tion of the Nurse's Home and adjacent car park.

\section{Professor Gerry Winter (1983-} 1993)

With Professor Gerry Winter as dean,

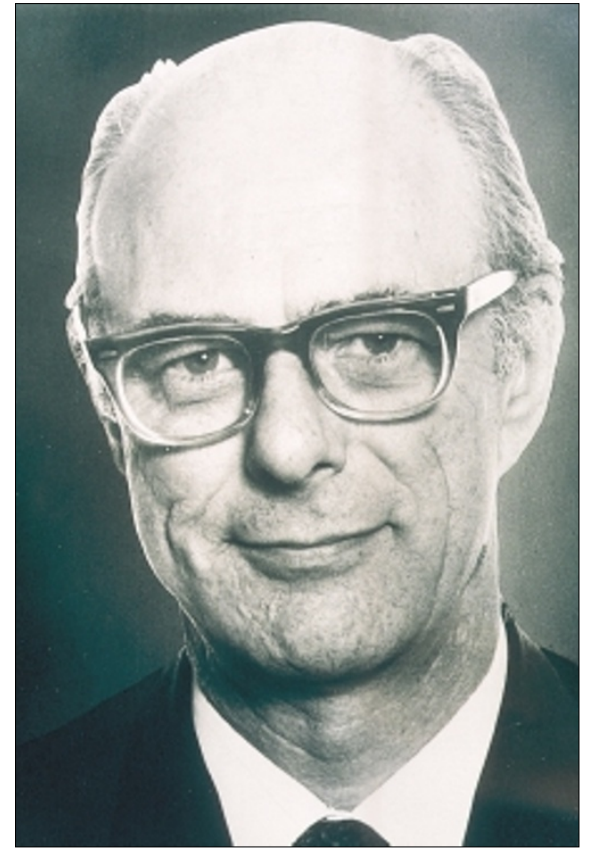

Professor Ivor Kramer

began the period of development and expansion.

By 1988 the refurbishment of the old Royal Free Hospital, including the Levy Wing and the Eastman building, was complete and opened by Princess Anne.

Research facilities were extended with the St Mary's Kodak money, and the intake of MSc, M PhiL and PhD students increased from 50 to 120 full time equivalents per annum. Fee income was also enhanced by the creation of the Dental Practice Centre in the Levy Wing for general dental practitioner courses.

New departments included Dental Public Health, headed by Professor Martin

\begin{tabular}{|l|ll|}
\hline Table 1 & & MSc Programmes \\
& & \\
1968 & 1 year & Conservation, oral pathology, prosthetics \\
1969 & 1 year & Paedodontics, oral surgery, periodontology \\
1976 & 2 year & Orthodontics \\
1979 & 2 year & Oral surgery \\
1985 & & Oral medicine \\
1986 & & Dental public health \\
1993 & & Endodontics \\
\hline
\end{tabular}

Downer, the former Chief Dental Officer with DoH funding. Oral Biology was created for Professor Peter Thorogood who was head hunted by Child Health three years later, but tragically he died in 1998 in a climbing accident. A joint Chair in Maxillofacial Surgery was established with University College and Joint Departments were created with the London Hospital Dental Institute in Oral Pathology and Biomaterials Science led by Paul Speight and Gavin Pearson.

Just before she died of osteosarcoma of the mandible Nicola Boissard, with the support of her mother Barbara Boissard, endowed the nucleus of a fund to establish a chair in Oral Biochemistry in the department of Oral and Maxillofacial Surgery to which Brian Henderson was appointed in 1992. This was an outstanding investment for science at the Eastman and has now been renamed the Boissard Chair in Cell Biology.

General management took over from the traditional Hospital Secretary in the form of Sotiris Argyrou, 1988 until 1992 and then Giles Denham from 1993 to 1997, both of whom fully supported the work of the Institute.

In December 1993 the Victor Goldman Day Unit (VGU), commemorating Victor Goldman's life long dedication to dental anaesthesia and the Eastman, was opened by Princess Anne.

Another cloud appeared with the Thatcherite monetarist virus which produced a mutation of the paternalistic University Grants Committee to the disciplinarian Higher Education Funding Committee of England and Wales (HEFCE). One of its actions was to deprofessionalise the tradition of self-regulation in research. 'The exchequer equips them, educates them and pays them, but doesn't trust them'. Hence the RAE - the Research Assessment Exercise.

The Eastman started the RAE with a two in 1984, a three followed in 1988 and with all round substantial research effort a four was expected in 1992. The blow struck with a two, which strongly suggested some miscalculations. But there was no HEFCE appeal mechanism, and so the Institute, 


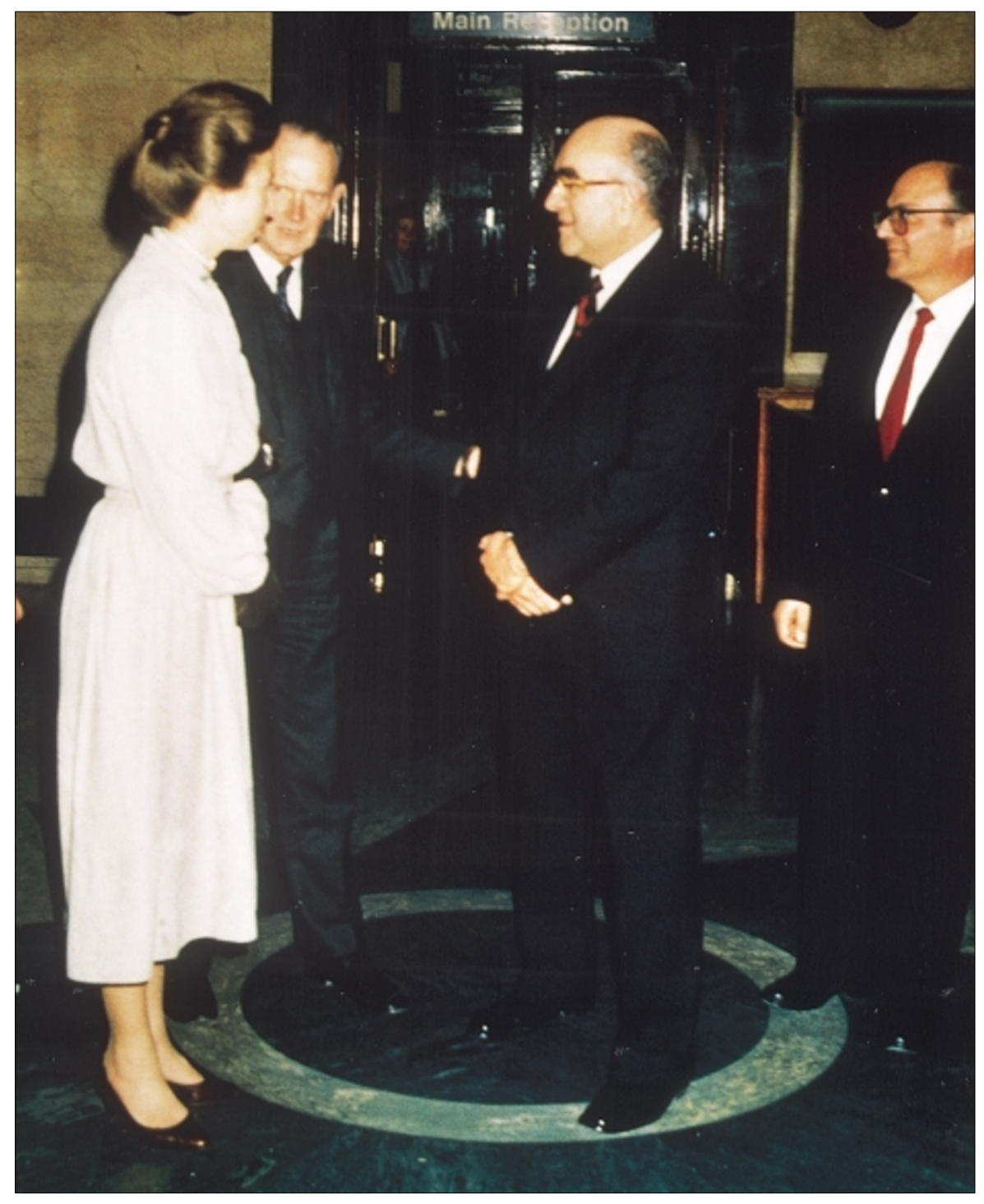

Professor Gerald Winter greeting Princess Anne on the occasion of the official opening of the Victor Goldman Day Case Unit. To her right is Michael Edwards, Chairman of the Committee of Management, and behind Professor Winter is the late Sotiris Argyrou who was then General Manager of the Eastman Dental Hospital.

nobly led by Gerry Winter, applied to the High Court for a judicial review, which was heard in the summer of 1993. The case was lost on the grounds that there could be no investigation of the process. However the review was to reveal bizarre and arbitrary scoring on the backs of envelopes, and it also demonstrated the true strength of the Eastman's research submission and most important of all it gained widespread support for radical change in the assessment process. ${ }^{12,13}$. Gerry Winter's politically courageous action did not get the appreciation it deserved.

The Institute changed its title to Eastman Dental Institute in 1992.

\section{Professor Crispian Scully (1993 - )}

1993 saw the appointment of Crispian Scully as Dean and changes in style were noticeable by lunchtime. There began a period of manic hyper-documentation. Forests fell as departmental profiles, CVs, scientific papers and grant applications were demanded. The Scots and Baltic landscape were only saved by the introduction of Intranet electronic mail.

HEFCE had decreed that with the dissolution of the Postgraduate Medical Federation, funding would be channelled through the principal university colleges; Kings, Queen Mary - Westfield, Imperial and University College. A merger with the London Dental Institute seemed to some to provide academic critical mass north of the Thames. However the possibility that there would be a transfer of research and science to Queen Mary College and a geographical chasm to bridge as part of the Royal London Hospital Trust suddenly became apparent and at the last minute the Institute became affiliated with University College London with complete entry taking place in August 1999.
The Eastman success has been the sum total of the effort and talent of all its teachers, clinicians, scientists and postgraduates. However Harvey Jacob Burkhart must not to be forgotten. It was his influence that won Eastman's support for dentistry...as part of his visionary concept of public dental health.

This made it logical for the Eastman Dental Hospital's entry into the University College London Hospitals Trust in 1996. EDH is now part of a large complex of medical and surgical excellence, which is geographically right for clinicians, managers, students, and patients. A new hospital is to be built and the old elegant University College Hospital cruciform building has been refurbished as a world centre for medical research. The Eastman and National Hospital for Neurology and Neurosurgery will remain on their present sites.

Oral Medicine re-emerged as an independent department with a Dental Special Needs Unit. The Institute also exploded with Chairs in Transcultural Oral Health, Oral and Maxillofacial Implantology, Dental and Medical informatics. The National Centre for Continuing Professional Education of Dentists, supported by the Department of Health, was established with a 
national and international tele-dentistry distance learning network; a newly refurbished Information Centre and Library embodies latest information technology with website, intranet lectures and handouts on the screen, supported by an outstanding Audio Visual Media group.

The great event of 1997 was the Research Assessment Exercise (RAE) rating of five for which Crispian Scully's presentation must be given full credit. This brought the restoration of HEFCE bonuses and academic confidence. Two years later the Quality Assurance Agency review of teaching, the TAE, gave a 23 out of 24 .

\section{The Future}

The Institute and Hospital are now part of a stimulating University Hospital complex, together with a unique group of postgraduate institutes constituting a faculty in its own right. This has facilitated the creation of an Eastman Head and Neck Pathology Unit serving both the University College Hospitals and Royal Free Trusts.

The Eastman Dental Hospital has built the Burkhart Dental Therapists School sponsored by the former Anglia and Oxford Health Authority, which will strengthen the educational spectrum of both Hospital and Institute.

The International Centre for Excellence in Dentistry (ICED) at 123 Grays Inn Road has been established to relate the highest quality private practice with teaching and clinical research.

The Eastman success has been the sum total of the effort and talent of all its teachers, clinicians, scientists and postgraduates. However Harvey Jacob Burkhart must not to be forgotten. It was his influence that won Eastman's support for dentistry, and his initiative that created a postgraduate school and clinic for children's dentistry and dental hygienists, as part of his visionary concept of public dental health. Without Burkhart's ambitious initiative there would not have been specialist clinics in Stockholm, Brussells, Paris, Rome and in the Grays Inn Road, London. Tribute must also be paid to George Eastman himself who was industrious and ingenious beyond belief, a man who may not have been above industrial spying,

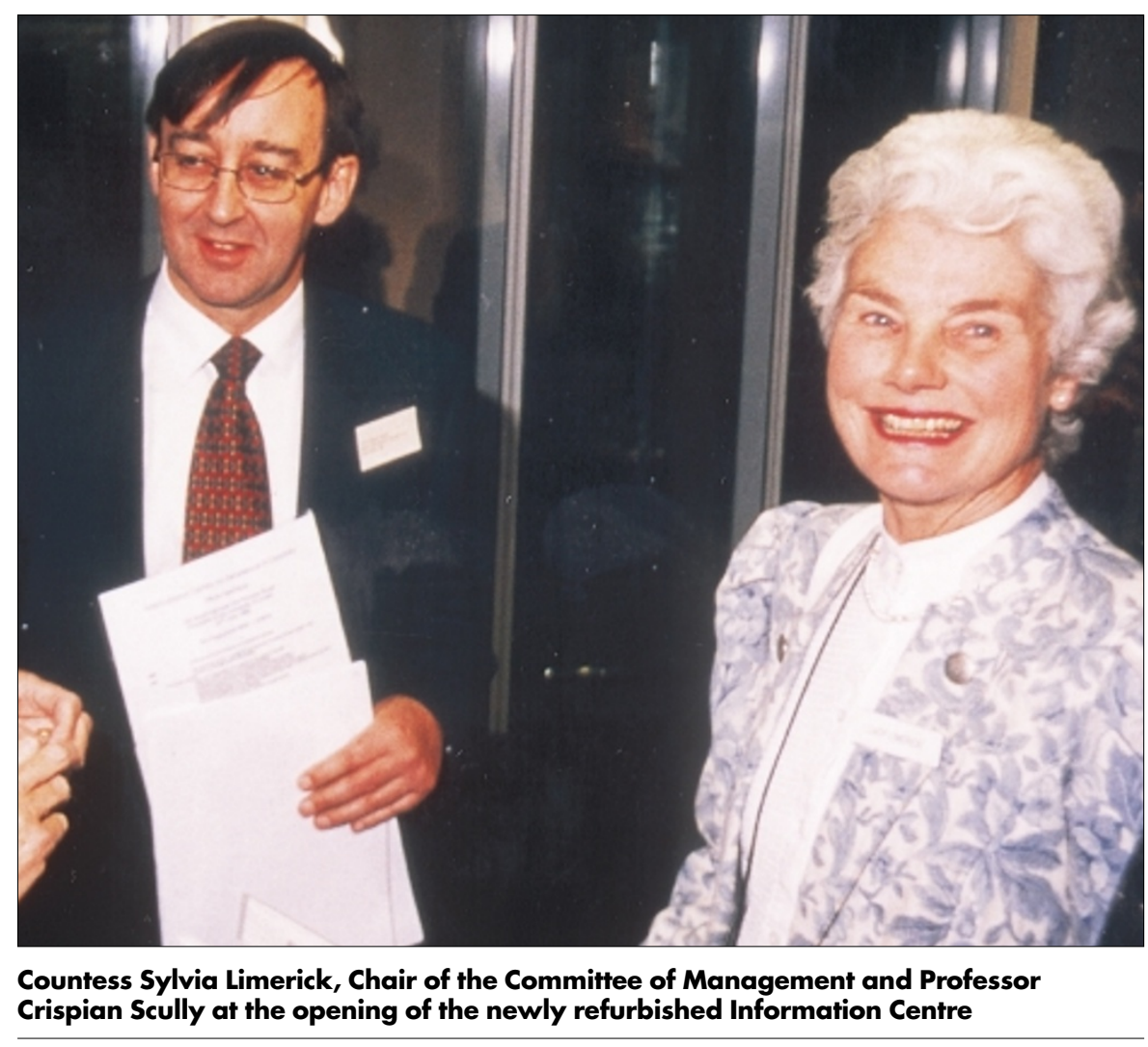

the exploitation of patents and ruthless in his elimination of competitors world-wide. Yet he invested millions of dollars in education, opposed racism in education and the workplace, was concerned about health care, especially dentistry, funded low cost housing, and the urban green environment and supported the arts, especially music. He undoubtedly identified with Kierkegaard; history has to do with results, motives and intentions are the business of ethics.

\section{Acknowledgements}

I must thank Lynn Amidon, archivist of the Royal Free Hospital, Stephen Blake, Alyson Chant, Giles Denham, Caroline Fox, Avril Gardner, John Galloway, Jean Gorham, Naomi Harris, Mat Hunt, Pat Johnson, Ivor Kramer, Peter Lewis librarian of the Eastman School of Music, Sylvia Limerick, Miles Maidment, Orvieto McGowan, Sajeda Meghii, James Morgan, Sheila Morgan, the Royal College of Surgeons Library, Yvonne Shirley, Gerry Winter, and Michael Wise for their invaluable contributions.

1 Hopkins J. Brayer George Eastman, A Biography. University Press, Baltimore and London 419-427, 1996.
2 Flexner A.Carnegie Bulletin Number Four (1910)

3 Bonner T N, Searching for Abraham Flexner Acad Med 1998; 73; 160-166

4 Flexner A. I remember, An Autobiography Simon and Schuster, New York, 1960

5 Kornberg A. For The Love Of Enzymes, The Odyssey Of A Biochemist. Cambridge: Harvard University Press, 1989.

6 Endicott C L. Postgraduate Training for Dentists; Brit Dent J 1938; 64: 3-12.

7 Ballard C. Personal letter and Supplementary Memorandum on Research and Postgraduate Study by F. Ballard. The Dental Board, October 1937

8 Deverell A C. The Institute of Dental Surgery and the Eastman Dental Clinic. Brit Dent J 1949; LXXXVI: 36-38.

9 Downton D. Frank Wilkinson : The Man. Brit Dent J 1986; 160: 395-397.

10 Wilkinson F W. Dental Education. Brit Dent J 1960; 109: 163-168.

11 Minutes of an Extraordinary Joint Meeting of the Dental Committee and the Academic Board; 26 November 1965.

12 Griffiths J. Give us the rationale for this painful exercise. The Times Higher Educational Supplement. April 18,1994: 12-1.

13 Maun L J and Sedley J. Regina v Higher Educational Funding Council. Exparte Institute of Dental Surgery. The Weekly Law Reports; Feb.18,1994: 242-263. 